\title{
STUDY OF SOLAR RADIATION AND WIND CHARACTERISTICS IN VARIOUS REGIONS OF UZBEKISTAN
}

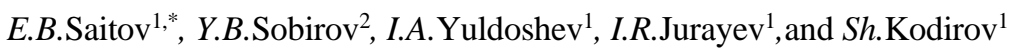 \\ ${ }^{1}$ Tashkent State Technical University, Uzbekistan, 100095, Tashkent, University St., 2 \\ ${ }^{2}$ Institute Of Materials Science RPA «Fizika-Solntsa» AS RUz., Uzbekistan, 100084, Tashkent
}

\begin{abstract}
The article discusses methods for monitoring solar radiation and wind characteristics and practical principles of use. The efficiency of using solar and wind energy largely depends on how accurately the design took into account specific data on the arrival of solar radiation or wind speed at the site of the intended operation of installations. The instability of the primary energy supply makes it necessary to supply the installations with accumulators, the choice of capacity of which also affects the size of the energy receivers, and therefore the technical and economic indicators.
\end{abstract}

\section{Introduction}

Over the past 15 years, renewable energy technologies have been actively developed in many countries of the world and have achieved technical and economic indicators showing their competitiveness with traditional technologies for the production of heat and electric energy based on the use of fossil fuels and nuclear energy. At present, with the total installed capacity of all power plants in the world around $5,000 \mathrm{GW}$, the capacity of existing power plants in the world using renewable energy technologies, excluding large hydropower stations, approached 1,000 GW and exceeded the capacity of all nuclear power plants (about $350 \mathrm{GW}$ ) by 3 times. Investments in renewable energy in recent years amounted to at least $\$ 250$ billion a year, which is 3 times more than in traditional energy and 5 times more than in nuclear and large hydropower. Since 2013, the annual commissioning of renewable energy in the world significantly exceeds the input of traditional power plants. The practical development of renewable energy is uneven across regions of the world. Its most rapid development takes place in countries heavily dependent on energy imports and having high energy tariffs. At the same time, even the fact that renewable energy in the foreseeable future will take a significant place in the energy of all countries, including those still rich in fossil fuel reserves. In this regard, support for research and development of promising technologies for the practical use of renewable energy sources is an urgent task for all countries concerned with the development of national scientific and technical competences in this promising area and the prevention of full technological dependence on the import of technologies and equipment in the future [1-4].

It is known that in the future, a characteristic feature of the development of modern energy is the broad involvement of the country's energy balance of renewable energy sources (RES). In a number of countries and regions, the share of electricity among RES generated by wind farms is a real competitor to traditional energy [4-6]. An estimate of the global potential of wind energy on the Earth's surface is about $1200 \mathrm{TW}$. Wind power is present today in more than 79 countries, of which 24 countries have more than $1 \mathrm{GW}$ of installed wind power capacity. According to the American electric power Institute (EPRI) today the price of electricity produced at the wind farms the US is 4-5 cents $/(\mathrm{kWh})$ and comparable to conventional power plants: nuclear 5-9, 4-5 thermal power plants gas and coal, $5-20$ cents/(kW/h) - HPS [7-10].

Solar, hydraulic and wind power are the main sources of renewable energy for large-scale industrial use in Uzbekistan. Local use of them in Autonomous power installations (sparsely populated mountain and rural areas, remote small consumers, etc.) is not considered in view of their small share in the electricity balance in the Republic.

According to the condition of their efficiency as power stations connected to the electric network of the regional branches of JSC "Regional electric networks" and the volume of availability for the conditions and climate of Uzbekistan, the above-mentioned RES for electricity generation are located in the specified descending order.

Introduction of renewable energy is one of the most important priorities of the transition of the economy of the Republic of Uzbekistan to innovative rails and environmentally friendly technologies. The relevance of this direction was once again emphasized in the Decree of the President of Uzbekistan Sh.M.Mirziyoyev dated may 26, 2017 No. RP-30-12 "On the program of measures for the further development of renewable energy, energy efficiency in economic and social sectors

*Corresponding author: elyor.saitov@mail.uz 
for 2017-2021". The decree is aimed at conducting scientific and practical research and developing a program of measures for the further development of renewable energy, as well as the practical use of wind energy, taking into account the climatic characteristics of the regions of Uzbekistan. The program for implementing the Decree provides for an increase in the generated renewable energy capacity up to 2021 of 1003.9 MW, including hydropower capacity by 601.9 MW, solar power by $300.0 \mathrm{MW}$, and wind power by 102.0 MW.

\section{Main Body}

\subsection{Theoretical analysis}

Currently, non-renewable energy resources (coal, oil, natural gas, nuclear fuel, etc.) are widely used to meet economic needs in all countries of the world.at the same time, highly developed countries with a population of $25 \%$ of all inhabitants of the globe consume $75 \%$ of all electricity, $79 \%$ of fuel, and $85 \%$ of wood [5-6]. The world's energy needs have increased exponentially throughout the entire period of its civilized history, all of which leads to the depletion of energy reserves, according to experts, by 2025 . there may be a shortage of them [7-8].Table 1 shows the characteristics of solar energy in the Republic of Uzbekistan.

Table 1.Characteristics of solar energy in Uzbekistan.

\begin{tabular}{|c|c|c|c|}
\hline № & Characteristics & Winter & Summer \\
\hline 1. & $\begin{array}{l}\text { Solar height } \\
\text { - north: } 45^{\circ} \quad 35^{\circ} \text { north } \\
\text { longitude } \\
\begin{array}{l} \\
\text { - south: } 37^{\circ} \quad 10^{\circ}\end{array} \\
\text { longitude }\end{array}$ & $\begin{array}{l}68^{\circ} \\
76^{\circ}\end{array}$ & $\begin{array}{l}21^{\circ} \\
29^{\circ}\end{array}$ \\
\hline 2. & $\begin{array}{l}\text { Duration of daily sunlight } \\
\text { (hours/days) }\end{array}$ & $\begin{array}{l}\text { In } \\
\text { average } \\
3-5\end{array}$ & $\begin{array}{l}10-13 \\
8-10\end{array}$ \\
\hline 3. & $\begin{array}{l}\text { Cloud days, average for the } \\
\text { year } \\
\text { - north } \\
\text { - south }\end{array}$ & $\begin{array}{l}45-50 \\
22-25\end{array}$ & $\begin{array}{l}10-15 \\
1-4\end{array}$ \\
\hline 4. & $\begin{array}{l}\text { Average duration of } \\
\text { sunlight, } \\
\text { hours/year } \\
\text { - north } \\
\text { - south }\end{array}$ & $\begin{array}{l}2800 \\
3050\end{array}$ & \\
\hline 5. & $\begin{array}{l}\text { Continuous solar radiation } \\
\text { intensity }\left(\mathrm{kW} / \mathrm{m}^{2}\right) \\
\text { - on the plane } \\
\text { - at high-altitude } \\
\text { actinometric stations } \\
\text { - at Kizilcha station, (height } \\
\text { more than } 3 \text { thousand } \\
\text { meters) } S_{\max }\end{array}$ & $\begin{array}{l}0,80-0,94 \\
0,94-1,06 \\
1,21\end{array}$ & \\
\hline
\end{tabular}

\subsection{Experimental part}

In this regard, the urgent problem is the problem of the use of renewable energy sources (RES), wind and solar energy etc. Moreover, when burning organic fuel, the atmosphere and the natural environment as a whole are polluted.

In Uzbekistan, since 1987, a Large Solar Furnace with a thermal capacity of $100 \mathrm{~kW}$ has been operated [3], and now, according to the press service of the Ministry of investment and foreign trade of Uzbekistan, the leading international company Masdar (UAE) will build one of the largest wind farms in the world with a capacity of $500 \mathrm{MW}$ in Navoi region. This is the second major project implemented by this company in the Republic of Uzbekistan - in October last year, Masdar won a tender for the construction of a $100 \mathrm{MW}$ solar power plant in the Navoi region on the basis of a publicprivate partnership. The relevant agreements for the implementation of this project were signed in January 2020 [9-10].

In order to measure solar and wind resources, modern automatic weather stations were built in six regions of Uzbekistan in 2013 [11-12]. in 2019, a meteorological mast with a height of $100 \mathrm{~m}$ was built in the Gallaaral and Forish districts of the Jizzakh region to study potential wind energy resources at the initiative of Uzbekgidroenergo JSC.

\subsection{The results and discussion}

For the purpose of efficient operation, wind farms are built in places where the wind speed is higher than 4.5 $\mathrm{m} / \mathrm{s}$. Automatic weather stations measure every second: solar energy flux densities, wind speeds and directions, ambient temperature, humidity, pressure, and visibility range. One of the six modern weather stations is shown in figure 1.

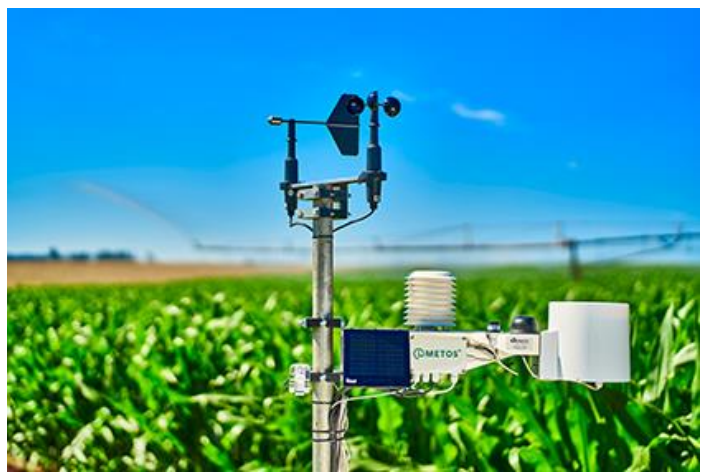

Fig. 1.Modern weather station installed in the Parkent region of the Tashkent region.

In meteorology, anemometers are used to measure wind speed. According to the principle of distinguish mechanical anemometers, where the motion of gas causes the rotation of the Cup wheel or impeller, thermal anemometers, whose operation is based on measurement of temperature reduction of the heated body (usually a heated wire), and the operation of the ultrasonic 
anemometer is based on measuring the speed of sound in flowing gas, depending on its speed.

Therefore, investors in the tender projects of a wind power plant (WPP) are guided by the use of expensive imported wind turbines. This increases the cost of electricity, hinders the development of wind energy, and the necessary solutions to reduce the cost of wind farms are the production of wind turbines in the Republic, using local raw materials.

In [19-22], we studied the formation of wind flows over the territory of Uzbekistan and their features due to the orographic parameters of the territory and synoptic processes occurring in the atmosphere that affect the characteristics of wind flows. When designing wind turbines, it is necessary to determine the wind potential of the area where construction is planned.

The analog electrical signal generated by the pyranometer is fed to the input of a pre-amplifier based on an instrumental differential amplifier. Due to the fact that the voltage of the pyranometer has a value of the order of millivolts, a low-noise OA should be used as an operational amplifier (OA). Further, the amplified signal is fed to the input of the ADC of the microcontroller for digital representation and for convenience of its further processing.

The principle of operation of the anemometer is based on counting the number of pulses per unit of time coming from the Hall sensor. A three-bladed impeller is used as a device that converts the wind flow into rotational motion. On the shaft of the three-bladed impeller there are two magnets, the fields of which cross the Hall sensor twice during the period of rotation of the impeller. The intersection of the Hall sensor with a magnetic field causes the generation of a rectangular electric pulse. By counting the number of pulses per unit of time, you can draw conclusions about the wind speed.

The efficiency of using solar and wind energy largely depends on how accurately the design took into account specific data on the arrival of solar radiation or wind speed at the site of the intended operation of installations. The instability of the primary energy supply makes it necessary to supply the installations with accumulators, the choice of capacity of which also affects the size of the energy receivers, and therefore the technical and economic indicators.

In General, information about solar radiation can be obtained in the following ways:

- analytical, when the necessary parameters for a specific geographical point are determined by calculation;

- long-term measurements at weather stations, the results of which are accumulated in climate reference books and databases;

-direct on-site measurements.

Analytical methods for determining solar radiation values are only suitable for preliminary assessment of the potential of individual regions, since their accuracy is low [23].

Currently, the main source of actinometric information is climate reference books created on the basis of processing the results of long-term meteorological observations. However, due to global changes in weather conditions, using only averaged long-term data will not be enough [24]:

Due to the increase in cloud cover, the annual duration of sunshine (ADS) for the period from 1955 to 2001 decreased by $3 \%$, and the number of days without Sun increased by $7 \%$. The most pronounced tendency to decrease PSS is in winter (17\%), and the weakest - in autumn $(3 \%)$.

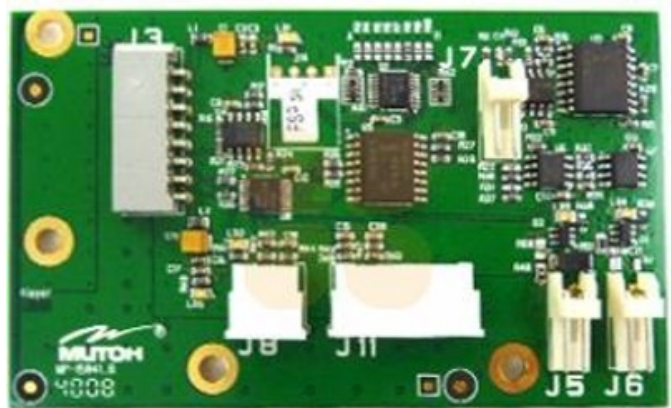

Fig. 2.Control Board Assembly.

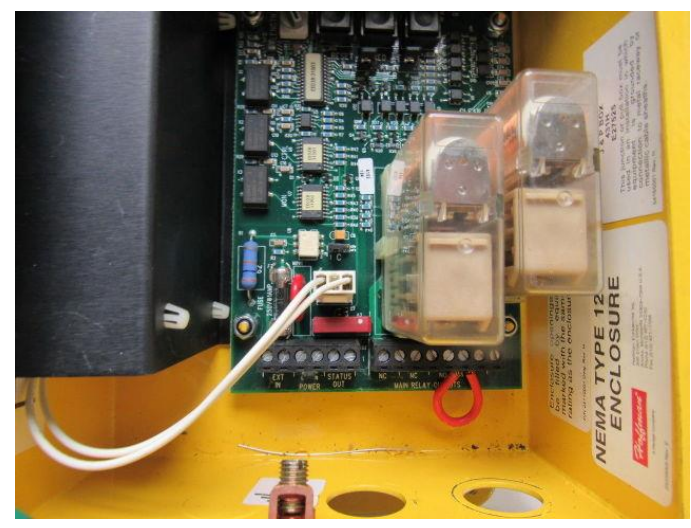

Fig. 3.The weather station body is glued together from $4 \mathrm{~mm}$ plexiglass and painted with gray nitrous paint. The back wall is made of $5 \mathrm{~mm}$ thick duralumin.

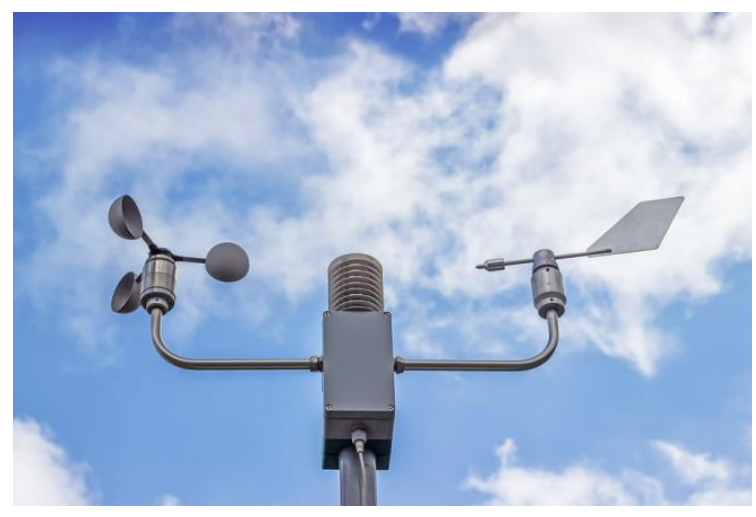

Fig. 4.Device for monitoring solar and wind characteristics.

Analysis of time series of annual amounts of components of the radiation balance for 1958-2001 showed a tendency to decrease (4\%) of direct, scattered and total radiation coming to the horizontal surface [25].

The need to minimize future losses of solar radiation requires more accurate consideration of local conditions, such as: dust levels, sources of local shading, local fog formation, etc. 


\section{Equations and mathematics}

To measure wind speed, Cup anemometers are often used, which are the most common type of anemometer, they are installed at a standard height of $10 \mathrm{~m}$ (see Fig. 1). As a rule, the heads of small wind turbines are located at a height of 5 to $50 \mathrm{~m}$. The approximation formula (1) is often used to determine the speed $v z$ of the wind at these heights (at height $\mathrm{z}, \mathrm{m}$ ), which includes the value of the standard wind speed $v_{\mathrm{s}}$ of the wind measured at height of $10 \mathrm{~m}$, namely [26]:

$$
\vartheta_{z}=\vartheta_{s}\left\{\frac{z}{10}\right\}^{b}
$$

where, $v_{z}-$ average wind speed at any height $\mathrm{z}, \mathrm{v}_{\mathrm{s}}-$ the wind speed at the standard height.

For open spaces, the parameter $b=1 / 7=0,14$. The lower the value of parameter $b$, the less the loads experienced by the wind wheel blade in the lower and upper positions will differ. As you know, the wind is a vector quantity, which, along with the average speed value, is also characterized by an instantaneous value - a gust. For fig. 5 and fig. 6 show the results of experimental measurements of gust and average wind speed at the Parkent weather station MHP MS4-12-1. They show the statistical nature of changes in these parameters over the course of a month, which should be taken into account when developing renewable energy sources.

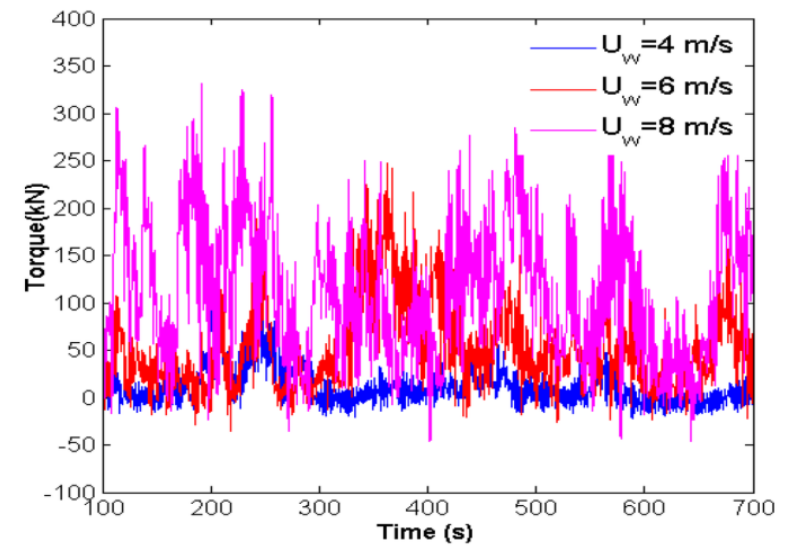

Fig. 5.Gust and hourly average wind speed values measured by the Parkent weather station MHPMS4-12-1 in the month of 2019.

In 2010, to study meteorological conditions at the selected site in the village of Yubileyny, Bostanlyk district, a meteorological mast with a height of $52 \mathrm{~m}$ was installed. Anemometric devices for 1.5 years, around the clock with an interval of 10 minutes recorded meteorological data, which later in Germany were processed by a special program. As a result of the research, an experimental wind power plant with a capacity of $750 \mathrm{~kW}$ was built in the village of Yubileyny, Bostanlyk district, Tashkent region.

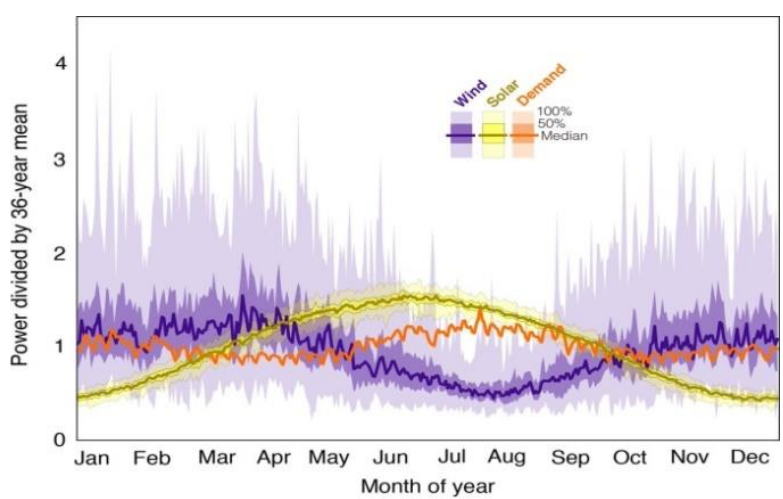

Fig. 6.Wind directions measured by the Parkent weather station MHPMS4-12-1 in 2019 (winddirection - wind direction relative to the North, winddirection StDev - standard deviation of the wind direction change within the measurement interval in degrees).

Based on the results of the data obtained, a project was developed, technical requirements for equipment were formulated, and a pilot wind power plant(WPP) was built. The generated electric energy of the WPP will be supplied to the unified energy network.Therefore, there is a need for direct measurements of the solar radiation or wind flux density at the site of the proposed installation, in addition, for statistically justified estimates, such measurements must be long-term (multiyear). Based on this, it was decided to develop an instrument complex for studying solar radiation and wind conditions [27-30].

\section{Conclusions}

The Autonomous measuring complex includes a device for recording total solar radiation, a device for recording wind characteristics, as well as units for Autonomous power supply, monitoring and storage of the received data. To register solar radiation, a thermoelectric pyranometer was selected that measures the total flux of solar radiation coming from the entire upper hemisphere. The sensor is placed under a transparent glass or plastic cover to protect it from precipitation, dust, and wind. An additional solar radiation sensor is a photovoltaic battery, which is used in the Autonomous power supply unit. A typical anemometer and wind direction meter are used to measure wind characteristics. Additionally, the ambient temperature is measured [31-40].

The control unit uses an AT mega 32 microcontroller, to which all sensors are connected via interface nodes, as well as an information storage unit that uses a large-volume semiconductor FLASH memory. The amount of memory is sufficient to store data for one year when using hourly averaging.

The system is a wind vane mounted on the shaft of the shank, which is driven in rotation by the incoming flow of wind. A system of radially positioned reed switches is used to estimate the wind direction. A magnet is attached to the shaft of the direction indicator. In relation to the reed switches, the magnet is positioned in such a way that passing over the corresponding reed switch during the rotation of the shank, its magnetic field 
causes the reed switch to close. Judging by which reed switch is closed, you can estimate the wind direction.

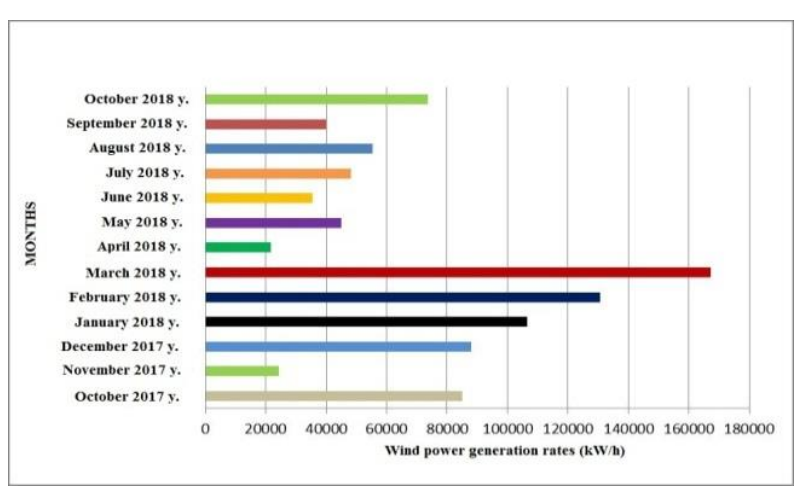

Fig. 7.Indicators of power generation of WPP with a capacity of $0.75 \mathrm{MW}(\mathrm{kWh})$ for months).

The electronic unit responsible for collecting and processing information is built on the basis of a microcontroller and has the following features and functions:

Amplification and conversion of the signal coming from the pyranometer to assess the degree of illumination;

Counting the number of pulses coming from the anemometer to calculate wind speed;

Analysis of which of the weather vane's reed switches is currently closed to determine the wind direction;

Display of current information (wind speed and direction, light level, date/time) on the LCD display (Fig. $2,3,4)$;

The presence of a push-button menu that allows you to organize the user interface with the electronic unit;

Ability to write current data to an SD card for collection and analysis over the course of a year.Autonomous power supply of the electronic unit from the battery, with the possibility of recharging it both from the mains and from the solar battery.

Data on the power generation of a wind power plant(WPP) connected to the Central network is recorded by a remote monitoring system. The results of monitoring from October 2017 to October 2018 are shown in figure 7.

As can be seen from Fig. 5, by maintaining the constancy of the air flow velocity, the amount of electricity generated also increases. However, the analysis shows that the lower power generation of the WPP is explained as follows, if the wind speed is less than $4 \mathrm{~m} / \mathrm{s}$, the WPP will not generate electricity. At a wind speed of $14-15 \mathrm{~m} / \mathrm{s}$, the WPP generates $750 \mathrm{~kW}$ of rated power. It should be noted that in order to get a more complete picture of the operation of the station, it is necessary to perform at least a year of monitoring of its operation.

In Uzbekistan, solar and wind resources are monitored using automatic measurement systems. Longterm averaged weather data allows you to determine the optimal installation locations and types of solar and wind power plants that work effectively with such resources.
Thanks to Academician M.K.Bahadirkhanov and Professor N.F.Zikrillayev for discussing the results and valuable advice.

\section{References}

[1] Finlay Colville, Prod. \& insp. Prod. Tech. USA, 7477 (2009)

[2] Chen Jiahe, al et., (RRL)-5, 8, 277-279 (2011)

[3] I. Sapaev, E. Saitov, N. Zoxidov, B. Kamanov, IOP Conference Series: Materials Science and Engineering 883, 1, 012116 (2020)

[4] J. Toshov, E. Saitov, E3S Web of Conferences RSES 139, 01087, 1-4 (2019)

[5] M.K. Bakhadyrkhanov, S.A. Valiev, N.F. Zikrillaev, S.V. Koveshnikov, E.B. Saitov, S.A. Tachilin, Applied solar energy 52, 4, 278-281 (2016)

[6] Sh.A. Faiziev, Yu.B. Sobirov, Applied Solar Energy 53, 1, 57-60 (2017)

[7] Electronic resource Available at: https://kun.uz

[8] S. Fayziev, Y. Sobirov, S. Makhmudov, I. Jof, Sand GE 7, 4, 21-28 (2018)

[9] V.S. Krivtsov, A.M. Oleynikov, et al., Textbook (Inst. Sevast, Sevast. NATs. tehn. Univ., 2003) 400

[10] E. Saitov, IJARSET 3, 5 (May 2016)

[11] V.S. Krivtsov, A.M. Oleynikov, et al., Inexhaustible energy (KN. 2. Univ., 2004) 519

[12] V.G. Derzky, Power engineering and electrification, 1, 53-56 (2010)

[13] U.A.Tadzhiev, E.I. Kiseleva, M.U. Tadzhiev, R.A. Zahidov, Part I, Solar Energy Equipment, 3, 46-52 (2014)

[14] R.A. Community, V.M. Kremkow, Solar technology 4, 106-107 (2015)

[15] M.V. Zavarina, (L., Hydrometeoizdat, 1971) 162

[16] E.B. Saitov, JMSChE 4, 30-35 (2016)

[17] S.Q. Shoguchkarov, T.R. Jamolov, N.Y. Mukhtarov, I.A. Yuldoshev, Applied Solar Energy 54, 392-394 (2018)

[18] M.K. Bakhadyrkhanov, S.A. Valiev, N.F. Zikrillaev, S.V. Koveshnikov, E.B. Saitov, S.A. Tachilin, Geliotekhnika 4, 28-32 (2016)

[19] I. Sapaev, E.B. Saitov, N. Zoxidov, B. Kamanov, Conmechydro - 2020 IOP Conf. Series: Mat. Sci. Eng. 883, 012116 (2020)

[20]E.B. Saitov, J.B. Toshov, Sh.B. Umarov, B.H. Fayzullayev, I.A. Abdullabekov, B.A. Nasriddinov, JCR 7, 15 (2020) ISSN 2394-5125

[21] E.B. Saitov, A.O. Pulatov, JCR 7, 15 (2020) ISSN 2394-5125

[22] N. Zikrillayev, E.B. Saitov, Monograph (LAP LAMBERT Academic Publishing, 2019) ISBN $987-$ 620-0-50311-4

[23] N. Zikrillayev, E.B. Saitov, Sbor. Mat. Mej. Nau. ret. Onl. Konf., 53-60 (28 May 2020) 
[24]E.B. Saitov, J. Toshov, S. Umarov, Boxodir Nasriddinov. Sbor. Mat. Mej. Nau. - ret. Onl. Konf., 329-339 (28 May 2020)

[25] N.F. Zikrillayev, E.B. Saitov, VestnikTashGTU 1, 51-56 (2018)

[26] B.A. Abdurakhmanov, M.K. Bakhadirkhanov, H.M. Iliyev, E.B. Saitov, et al., Nanoscience and Nanotechnology 4, 3, 41-43 (2014)

[27]B.A. Abdurakhmanov, M.K. Bakhadirkhanov, E.B. Saitov, et al., Nanoscience and Nanotechnology 4, 2, 23-26 (2014)

[28]X.M. Iliyev, E.B. Saitov, S.X. Saydaliyev, S.A. Tachilin, Prob. ener- i res., TashGTU 1-2, 183185 (2014)

[29] I.A. Yuldoshev, S.K. Shoguchkarov, A.R. Kudratov, T.R. Jamolov, Applied Solar Energy (English translation of Geliotekhnika) 56, 2, 125-130 (2020)

[30] S.Q. Shoguchkarov, T.R. Jamolov, N.Y. Mukhtarov, I.A. Yuldoshev, Applied Solar Energy (English translation of Geliotekhnika) 54, 5, 392-394(2018)

[31] M.N. Tursunov, V.G. Dyskin, I.A. Yuldashev, K. Sobirov, P.J. Hwoan, Applied Solar Energy (English translation of Geliotekhnika) 51, 2, 163164 (2015)

[32] M.N. Tursunov, V.G. Dyskin, B.M. Turdiev, I.A. Yuldashev, Applied Solar Energy (English translation of Geliotekhnika) 50, 4, 236-237 (2014)

[33]M.N. Tursunov, K. Sabirov, P.J. Hwoan, A.R. Shirmatov, I.A. Yuldoshev, Applied Solar Energy (English translation of Geliotekhnika) 49, 4, 232-234 (2013)

[34] M.N. Tursunov, R.A. Muminov, V.G. Dyskin, I.A. Yuldoshev, Applied Solar Energy (English translation of Geliotekhnika) 49, 1, 16-18 (2013)

[35] M.N. Tursunov, R.A. Muminov, O.F. Tukfatullin, I.A. Yuldoshev, E.T. Abdullaev, Applied Solar Energy (English translation of Geliotekhnika) 47, 1, 63-65 (2011)

[36] T.T. Riskiev, M.N. Tursunov, S. Dadamukhamedov, I.A. Yuldoshev, M.S. Yakubova, Applied Solar Energy (English translation of Geliotekhnika) 46, 4, 248-250 (2010)

[37] I. Sapaev, E. Saitov, N. Zoxidov, B. Kamanov, IOP Conference Series: Materials Science and Engineering 883, 1, 012116 (2020)

[38] J. Toshov, E. Saitov, E3S Web of Conferences 139, 01087 (2019)

[39] T.T. Riskiev, M.N. Tursunov, S. Dadamukhamedov, O.F. Tukfatullin, I.A. Yuldoshev, Applied Solar Energy (English translation of Geliotekhnika) 46, 3, 179-181 (2010)

[40] M.K. Bakhadyrkhanov, S.A. Valiev, N.F. Zikrillaev, E.B. Saitov, S.A. Tachilin, Applied Solar Energy (English translation of Geliotekhnika) 52, 4, 278281 (2016) 